\title{
Ecosystems' economic assessment in the context of different climatic zones
}

\author{
Vera Yurak, Evgenia Emelyanova, and Tatyana Kostromina
}

Ural State Mining University, 620144, 30, Kuibyshev st., Ekaterinburg, Russia

\begin{abstract}
The failure of the key approach to assessing the value of natural goods, based only on the assessment of providing value, provoked the emergence of the ecosystem services' theory. In addition to providing services of nature this theory includes supporting, regulating and social or cultural services. This approach provoked further adjustment of the state regulation system in the way of developing the market of ecosystem services, considering the full range of services provided by nature to society, for the organization of a transparent mechanism for the use of natural resources and ecosystem services. However, to date, in the Russian Federation this approach has not received legislation support, but the academic community is actively working on this aspect and even suggests adding the value of ecosystem services in the methodology for assessing the national wealth. The economic assessment of real and potential damages from ecosystems' degradation using the theory of ecosystem services becomes extremely important for the development of an algorithm for optimal natural resource management at various levels of state regulation. The results of the study are the identified boundaries of economic assessment of the value of ecosystems (soil and forest) in the context of 1) valuation methods and 2) climatic zones in order to identify the most valuable ecosystems for simplifying the processes of natural resource management.
\end{abstract}

\section{Introduction}

Awareness about the issue of failure of the key approach to assessing the value of natural goods, based only on the assessment of resource related / providing value, provoked the emergence of the ecosystem services theory, which incorporates supporting, regulating and social/cultural function in addition to resource related / providing service of nature. Such an approach provoked a demand for further adjustment of the public regulation system to promote development of environmental (ecosystem) services market, taking into account the full range of services provided by the environment to the community, and establishment of transparent procedure of natural resources and ecosystem services management. Nevertheless, to date, this approach has not received legislative support in the Russian Federation, but the academic community is doing their best to address this issue and even suggests adding the value of ecosystem services in the methodology for assessing the national wealth. In the light of existing issues the economic assessment of actual and potential damages due to ecosystem degradation by means of ecosystem services theory becomes 
critical for development of algorithms of the most effective natural resources management at different levels of regulation. Based on results of this study, the boundaries of economic assessment of the value of ecosystems (soil and forest) were identified in the context of 1) valuation methods according to ecosystem services theory and 2) climatic zones, in order to identify the most valuable ecosystems and to improve and simplify the processes of natural resource management.

One of the major challenges from the Russian Federation's scientific and technological development point of view is increase of man-induced impacts on the environment to such scales that present a threat to restoration of natural resources and ecosystem services, and increasing life and health risks for the population, connected with their ineffective management [1]. This is caused by continuing ideological repercussions of the front-end (cowboy) economics, which viewed the natural resources as source of raw materials only, i.e. their resource related or providing service was used. It became clear afterwards that the key approach to assessment of the value of natural resources, based on resource related / providing value does not enable relevant assessment of value of the environment for life of society. The market price considering the providing aspect only is not a sufficiently accurate indicator of the environment value for the community. A demand arose to identify the actual value of nature, taking into consideration all the services provided by nature to humans. This is how the ecosystem services theory emerged. It incorporates supporting, regulating and social/cultural function in addition to resource related / providing service of nature. Such an approach drove the demand for further adjustment of the public regulation system to promote development of environmental (ecosystem) services market, taking into account the full range of services provided by the environment to the community, and establishment of transparent procedure of natural resources and ecosystem services management.

Nevertheless, to date, this approach has not received legislative support in the Russian Federation, but the academic community is doing their best to address this issue and even suggests adding the value of ecosystem services in the methodology for assessing the national wealth. In the light of existing issues the economic assessment of actual and potential damages due to ecosystem degradation by means of ecosystem services theory becomes critical for development of algorithm of the most effective natural resources management at different levels of regulation.

Further, anthropogenic activity is the main burden for the environment; that is human activities resulting in damage of land and, consequently, deterioration of the entire terrain and ecosystems existing therein, therefore this study focused on soil ecosystems and forest ecosystems as target of research. The very definition "soil ecosystems" was used, since other ecosystems with sufficiently high value of the pedosphere apart of agricultural ecosystems were subject to the assessment. No terminological problems are observed with regard to the forest ecosystems.

The goal of this study is to outline the boundaries of economic assessments of the value of ecosystems (soil and forest) in terms of 1) valuation methods according to ecosystem services theory, and 2) climatic zones in order to improve and simplify the processes of natural resources management.

The following objectives were specified in order to reach the specified goal:

1. Determining frequency of use of economic assessment methods for identification of value of soil and forest ecosystems;

2. Reduction of economic assessments to comparable values as on 01.01.2020;

3. Outlining the boundaries of economic assessments of the value of ecosystems (soil and forest) in terms of valuation methods and climatic zones.

The following limitations were introduced: 1) number of analyzed studies focused on economic assessment (up to 10 for each ecosystem studied); 2) only temperate climate zone 
ecosystems were subject of the study concerning the forest ecosystems; 3) the value of soil ecosystems was assessed through evaluation of "soil erosion regulation" service only.

\section{Materials and methods}

The ecosystem services theory became theoretical and methodological framework of this study, since increasing scarcity of global natural resources keeps recent development of wide range of issues connected with ecosystem services up to date (included but not limited to their identification, assessment, identifying potential vendors and customers, compensatory strategies, establishing the markets of these services). Baseline concept of ecosystem services theory is chargeability of the ecosystem services that nature provides to humans. Therefore, having assessed the value of ecosystem services provided by specific ecosystems the most favorable option of their utilization can be identified.

\section{Results and discussion}

The following results have been obtained after implementation of the first objective (Determining frequency of use of economic assessment methods for identification of value of soil and forest ecosystems):

Regarding soil ecosystems, the following methods were used for analysis of "soil erosion regulation" ecosystem service in terms of different climate zones: 1) market prices method; 2) contingent preference valuation and 3) method of scoring. All methods have been presented in the summary diagram for illustration (Fig. 1).

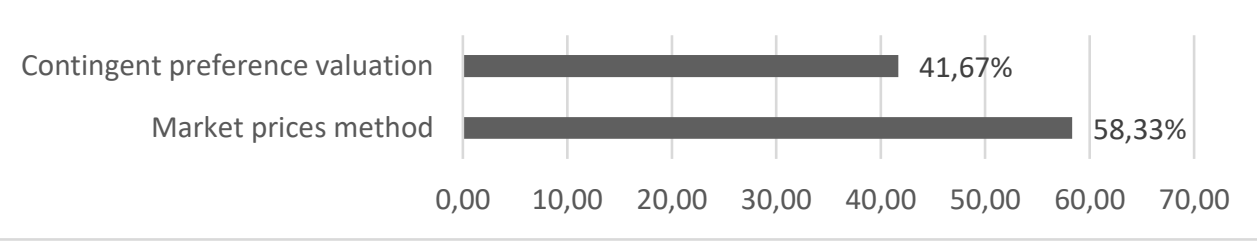

Fig. 1. Valuation methods for "soil erosion regulation" ecosystem service

The diagram shows that the market prices method was used frequently for economic assessment of the "soil erosion regulation" ecosystem service, since it is quite easy to use this method in conditions of development of the Internet and availability of information concerning costs of particular natural resources, land in this instance.

Forest ecosystems: the following methods were used for analysis of the forest ecosystems: 1) market prices method; 2) replacement costs method; 3) analogue method. All methods have been presented in the summary diagram for illustration (Fig. 2).

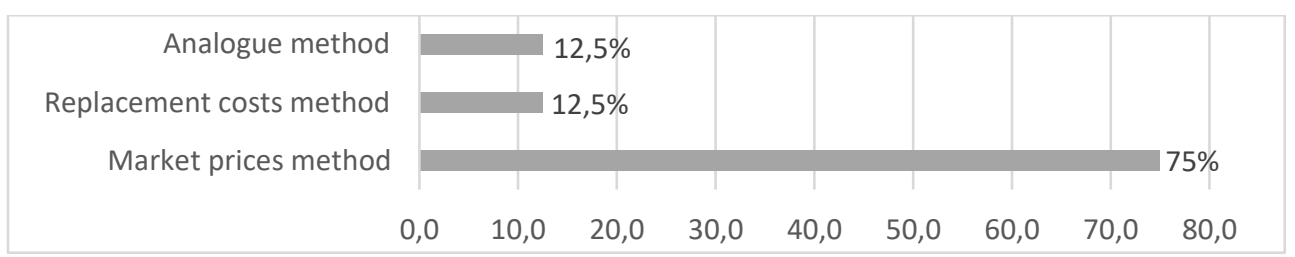

Fig. 2. Methods of economic assessment of forest ecosystems services within temperate climate zone

The diagram shows that the market prices method was used frequently for economic assessment of the forest ecosystems service of the temperate climate zones, since this 
ecosystem has the market represented by vendors and customers. Replacement costs method and analogue method take up less in this diagram, since the least consideration is given to particulars of specific regions locating the ecosystems analyzed by these approaches.

The second specified objective (viz. Reduction of economic assessments to comparable values as on 01.01.2020) was addressed by means of discounting tools. The rate of return was determined as the average RF Central Bank base rate for each year.

To implement the third specified objective (Outlining the boundaries of economic assessments of the value of ecosystems (soil and forest) in terms of valuation methods and climatic zones) a table was made with specified intervals of economic assessments for soil ecosystems (refer to Table 1) and forest ecosystems (refer to Table 1).

Table 1. Valuation methods for "soil erosion regulation" ecosystem service of soil ecosystems

\begin{tabular}{|c|c|c|}
\hline Valuation method & $\begin{array}{l}\text { Economic assessment, US \$/ year } \\
\text { per ha* }\end{array}$ & References \\
\hline \multicolumn{3}{|c|}{ Tropical zone } \\
\hline contingent preference valuation & $6.15-97.24$ & {$[2],[4]$} \\
\hline \multicolumn{3}{|c|}{ Subtropical zone } \\
\hline market prices method & $3.17-56.11$ & {$[9],[10],[13]$} \\
\hline \multicolumn{3}{|c|}{ Subequatorial zone } \\
\hline market prices method & $1,858.61-47,415.72$ & {$[3],[7]$} \\
\hline contingent preference valuation & $384.67-12,873.59$ & {$[11],[12]$} \\
\hline \multicolumn{3}{|c|}{ Temperate zone } \\
\hline market prices method & $1,988.40-21,7565.64$ & {$[5],[6],[8]$} \\
\hline
\end{tabular}

*The economic assessments were reduced to values as on 01.01.2020, herewith discounting tools were used. The rate of return was determined as the average RF Central Bank base rate for each year.

As regards the value of soil ecosystems. express analysis suggests that it varies within range from 3.17 to $217,565.64$ US $\$$ /ha per year as of 01.01.2020. According to analysis of maximum limits of economic assessments, the soils of the temperate climate zone appear to have the highest value. The value of subtropical zone soils can be marked number two; the subequatorial zone soils come third, and the tropical zone soils rank the fourth value.

Therefore, the soils of temperate and subtropical zones are the most "expensive" ones for rehabilitation of damaged land, which should be taken into account at development of natural resources management projects within the boundaries of these climate zones.

Table 2. Evaluation of ecosystem services of forest ecosystems of the temperate climatic zone

\begin{tabular}{|c|c|c|c|c|c|}
\hline No. & $\begin{array}{c}\text { Method } \\
\text { description }\end{array}$ & $\begin{array}{c}\text { Frequency } \\
\text { of use, } \%\end{array}$ & $\begin{array}{c}\text { Averaged economic } \\
\text { assessment* }\end{array}$ & $\begin{array}{c}\text { Measurement } \\
\text { units }\end{array}$ & References \\
\hline 1 & $\begin{array}{c}\text { Market prices } \\
\text { method }\end{array}$ & 75.0 & $151.29-50,531,811.96$ & $\begin{array}{c}\text { US } \$ / \text { ha per } \\
\text { year }\end{array}$ & {$[14-18]$} \\
\hline 2 & $\begin{array}{c}\text { Replacement } \\
\text { costs method }\end{array}$ & 12.5 & $4,348.31$ & $\begin{array}{c}\text { US } \$ / \text { ha per } \\
\text { year }\end{array}$ & {$[19]$} \\
\hline 3 & $\begin{array}{c}\text { Analogue } \\
\text { method }\end{array}$ & 12.5 & $2,943,865.20$ & $\begin{array}{c}\text { US } \$ / \text { ha per } \\
\text { year }\end{array}$ & {$[20]$} \\
\hline
\end{tabular}

* The economic assessments were similarly reduced to the average values as on 01.01.2020. Discounting tools were used.

Express analysis indicated that the value of ecosystem services of the temperate climate zone forest ecosystems varies within quite extensive range of values from 151,29 to $50,531,811.96$ US $\$$ /ha per year, i.e. spot lab tests and field surveys of studied ecosystems 
are required for more accurate assessment of the value of specific ecosystems $[21,22,23]$. Nevertheless, obtained results of the study can be applicable for express evaluations.

\section{Conclusions}

This way, the goal of the study is met, since the boundaries of economic assessments of ecosystems' value (soil and forest ecosystems) were identified in terms of: 1) valuation methods according to ecosystem services theory, and 2) climatic zones in order to improve and simplify the processes of natural resources management. The market prices method is most frequently used for assessment of soil and forest ecosystems. The soils of subtropical and subequatorial zones were assessed more frequently, according to data provided by research of ecosystem services referred to as soil erosion regulation. The forest ecosystems were subjected to express analysis within temperate climatic zone only. A more accurate assessment of specific ecosystems is required to ensure sustainable development of the Russian regions and enhance their competitive power. This assessment can be facilitated by field studies conducted by experts in different scientific disciplines.

\section{Acknowledgement}

This work has been funded by the project of President of the Russian Federation for state support of young Russian scientists - candidates of sciences MK-190.2020.6 "Big data of ecosystem services' assessments of regions in the context of different physical and geographical zones.

\section{Reference}

1. The Strategy of Scientific and Technological Development of the Russian Federation approved by Decree of the President of the Russian Federation of December 1, 2016 No. 642 URL: http://www.consultant.ru/document/cons_doc_LAW_207967/

2. P.Asrat, K. Belay, D. Hamito, Land Degradation and Development, 15, 423-438 (2004) doi:10.1002/ldr.623

3. C.A.K. Bada, J. Hack, Ecological Indicators, 107 (2019) doi: 10.1016/ j.ecolmodel.2018.03.006

4. H. Daly-Hassen, P. Riera, R. Mavsar, A. Gammoudi, D. Garcia, Environmental Economics and Policy, 6(3), 268-282 (2008) doi: 10.1080 / 21606544.2017.1293566

5. A.R. Graves, J. Morris, L.K. Deeks, R.J. Rickson, M.G. Kibblewhite, J.A. Harris, T.S. Farewell, I. Truckle, Ecological Economics, 119(C), 399-413 (2015) doi: 10.1016/j.ecolecon.2015.07.026.

6. L. Hansen, Agricultural and Resource Economics Review, 36(2), 267-280 (2007) doi:10.1017/S1068280500007085

7. G. Hassen, A. Bantider, Geoenviron Disasters, 7, 5 (2020) doi: 10.1186/s40677-0190138-4

8. H. Lindhjem, T. Hu, Z. Ma, J. Skjelvik, G. Song, H. Vennemo, J. Wu, S. Zhang, Environmental Impact Assessment Review, 27(1), 1-25 (2007) doi: 10.1016/j.eiar.2006.08.004.

9. B. Martin-Lopez, M. Garcia-Llorente, I. Palomo, C. Montes, Ecological Economics, 70(8), 1481-1491 (2011) doi: 10.1017/S0376892907004067

10. K.N. Ninan, M. Inoue, Ecosystem Services, Elsevier, 5(C), 78-87 (2013) doi: 10.1016 / j.ecoser.2013.02.006 
11. J.M. Nyongesa, H.K. Bett, J.K. Lagat, O.I. Ayuya, Ecological Processes, 5(15), 1-15, (2016) doi: 10.1186 / s13717-016-0059-Z

12. T.D. Pham, N. Kaida, K. Yoshino, X.H. Nguyen, H.T. Nguyen, D.T. Bui, Ocean and Coastal Management, 163, 269-277 (2018) doi: 10.1016 / j.ocecoaman.2018.07.005

13. M. Rodriguez-Entrena, M. Espinosa, J. Barreiro-Herle, Ecological Economics, 99(C), 63-73 (2014) doi: 10.1016/j.ecolecon.2014.01.006

14. A. Chiabai, C.M. Travisi, H. Ding, A. Markandya et al., FEEM, 12, 12-42 (2009) doi: 10.1142/S2010007813400010

15. T. Häyhä, P. P. Franzese, A. Paletto, B. D. Fath, Ecosystem Services, 14, 12-23, (2015) doi: 10.1016/j.ecoser.2015.03.001

16. A. Paletto, C. Geitner, G. Grilli, R. Hastik, F. Pastorella, L. R. Garcia, Annals Forest Research, 58(1), 1-19 (2015) doi: 10.15287/afr.2015.335

17. E. T. Campbell, D. R. Tilley, Ecosystem Services, 7, 141-151 (2014) doi: 10.1016/j.ecoser.2013.10.003

18. X. Niu, B. Wang, S. Liu, C. Liu, W. Wei, P. E. Kauppi, Ecological Complexity, 11, 111 (2012) doi: 10.1016/j.ecoser.2017.05.012

19. L. Hein, Ecology and Society, 16(2), 13 (2011) doi: 10.5751 / ES-04119-160213

20. A. Mc Vittie, L. Brander, S. Hussain, A. Wagtendonk, P. Verburg, O. Vardakoulias, TEEB, 14-25 (2011)

21. M.N. Ignatieva, V.G. Loginov et. al., Ekonomika Regiona, 1-37, 102-111 (2014)

22. A.V. Dushin, V.V. Yurak, Eurasian Mining, 1, 11-15

23. D.S. Korelskiy, A.V. Strizhenok, D.V. Ismailova, Journal of Engineering and Applied Sciences, 15 (3), 342-353 (2020) 